\title{
Evaluation of Supply Chain Management Performance at MSMEs using the SCOR Method
} Evaluasi Kinerja Manajemen Rantai Pasokan di UMKM menggunakan Metode SCOR

Received:

16 December 2019

Accepted:

15 May 2020

Published:

19 August 2020

\author{
1*Felia Anjani, ${ }^{2}$ Muhammad Zhafari, ${ }^{3}$ Qurrotul Aini \\ ${ }^{1,2,3}$ Sistem Informasi, UIN Syarif Hidayatullah \\ 1,2,3 Jl. Ir. H. Juanda No. 95 Ciputat, Tangerang Selatan, 15412, \\ Indonesia \\ E-mail: ${ }^{1}$ felia.anjani17@mhs.uinjkt.ac.id, \\ ${ }^{2}$ muhammad.zhafari17@mhs.uinjkt.ac.id, ${ }^{3}$ qurrotul.aini@uinjkt.ac.id \\ *Corresponding Author
}

\begin{abstract}
The development of the industrial world that accelerates the growth of competition between businesses. It causes the need for activities or efforts to increase the selling power of the company or organization. One of them is by evaluating the level of performance in the supply chain at SME Tosuka Coffee. It is done to determine the level of current business conditions and to know what elements have good potential in business development and what components need to be improved. This evaluation uses the SCOR method in assessing supply chain performance. The assessment with SCOR is based on Tosuka's current condition. The results of this study state that the final value of the SCOR calculation yields a figure of 86.24, which means that Tosuka Coffee's business is at a good level, especially in the Plan process that receives the highest value with Responsiveness dimension and is followed by the Return process with the Reliability dimension. However, Tosuka Coffee is recommended to make performance improvements in the Make, Source, and Deliver processes because it produces a relatively low value. With the evaluation, it is expected that Tosuka Coffee can improve supply chain performance in the future.
\end{abstract}

Keyword - Supply Chain Management, SCOR, MSME

Abstrak-Perkembangan dunia industri yang kian pesat menyebabkan tingginya tingkat persaingan antar bisnis. Hal ini menyebabkan perlunya kegiatan atau upaya dalam meningkatkan daya jual perusahaan atau organisasi. Salah satunya dengan mengevaluasi tingkat kinerja dalam rantai pasok pada UMKM Tosuka Coffee. Hal tersebut dilakukan untuk mengetahui tingkat kondisi bisnis saat ini serta mengetahui elemen apa yang memiliki potensi baik dalam perkembangan bisnis dan elemen apa yang perlu ditingkatkan. Pengevaluasian ini menggunakan metode SCOR dalam menilai kinerja rantai pasok. Penilaian dengan SCOR dilakukan berdasarkan kondisi Tosuka saat ini. Hasil penelitian ini menyatakan nilai akhir dari perhitungan SCOR menghasilkan angka 86.24 yang berarti bisnis Tosuka Coffee berada di level yang baik (good) terlebih pada proses Plan yang memperoleh nilai tertinggi dengan dimensi Responsiveness dan disusul oleh proses Return dengan dimensi Reliability. Namun Tosuka Coffee disarankan untuk melakukan peningkatan kinerja pada proses Make, Source dan Deliver karena menghasilkan nilai yang tergolong rendah. Dengan dilakukannya evaluasi, diharapkan Tosuka Coffee dapat meningkatkan kinerja rantai pasok untuk di masa depan.

Kata Kunci-Manajemen Rantai Pasok, SCOR, UMKM 
INTENSIF, Vol.4 No.2 August 2020

ISSN: 2580-409X (Print) / 2549-6824 (Online)

DOI: https://doi.org/10.29407/intensif.v4i2.13993

\section{INTRODUCTION}

A supply chain is a supply chain that together carries out the role of its activities, which include funds, resources, and other related activities in creating a product. These roles include suppliers, distributors, factories, retailers, and other supporting parts such as logistics services. Supply chain activities include the supply of raw materials, production of goods, to sending to the last stakeholder [1]. At the same time, the meaning of Supply Chain Management is the activity of managing a unified process and events in the integrated supply chain in the form of products, services, and information [2].

This supply chain management activity will be evaluated by Tosuka to improve supply chain performance. Tosuka Coffee is a Japanese-style open bar concept coffee shop in the Micro, Small and Medium Enterprises (MSMEs). Tosuka, which means Tosca, has a similar meaning to the concept of design, packaging, and interior, dominated by Tosca's color. Tosuka Coffee was founded in 2018 by one of the coffee fans and connoisseurs. The menu offered at Tosuka Coffee is diverse, ranging from Espresso-based coffee, Manual Brew coffee, Japanese specialty coffee in the seasonal menu, and frappe drinks with premium powder ingredients.

Generally, every business must have a predetermined profit target. However, based on the interview results, there were problems at the UMKM Tosuka, including profit targets that did not reach ROI (Return of Investment), lack of accuracy in carrying out stocktaking regularly made sometimes errors in delivery occur. Also, there is often a loss of communication in the operational part in the fulfillment of raw materials, making it necessary to carry out supply chain evaluation activities. This evaluation was carried out to determine the current condition of the UMKM Tosuka and any attributes that have high potential and need to be improved in the supply chain at Tosuka. To achieve success in implementing the supply chain. So, the performance evaluation results can be used as a reference for companies to achieve goals and improve competitiveness [3].

In a study needed the support of the results of previous studies relating to MSMEs. As in previous studies, the development of supply chain performance at MSMEs has resulted in some MSMEs implementing a good partnership system with suppliers that aim to maintain product quality [4]. While other UMKM management research argues, the need to pay attention to the continuity of the supply of raw materials for the smooth running of the business. Good cooperation between companies and suppliers must be established, overcome the increase in amount flows, and join existing business cooperatives [5]. Other research concludes, by using SCM, the company makes all management data related to supply chain management starting from the main thing until the supporting part can be integrated. As for some supply chain 
elements that are not present in both systems. These are elements of the plan that are not found in ERZAP and layout and production elements that are not in Tradegecko [6].

Taking references from other studies that apply the SCOR model, the results have been obtained. Namely, a performance that was previously still experiencing fluctuations is now in the best position, especially in the attributes of responsiveness and flexibility, while overall, the cost attribute in the organic vegetable supply chain has not reached the best performance and still needs to be improved [7]. A similar study that was initially constrained because changes in the number of raw material orders resulted in a buildup, now produces a total value of performance in the supply chain that can be classified into the average category in the monitoring system [8]. Other studies combine the SCOR method with AHP yields; measurements of performance attributes obtain values that are included in the average group, which previously had constraints, namely lack of productivity in the product's capacity to expand. In the process of Make, Return, and Deliver still need to be increased productivity [9]. The dimension of performance metrics that gets the highest score and has a high priority is the Make process, with the Reliability dimension. Therefore the current performance is classified as good (good) [10],[11]. And in other studies, it is known that the application of supply chains has a positive influence on the level of integration and competitive capability where competitiveness is very important for company performance [12].

This research aims to measure the level of performance of supply chain management in MSME type businesses. Is it included in the good category? Should there be an increase in certain parts? Is it important for supply chain management in MSMEs? We propose that this performance evaluation activity be carried out using the SCOR method.

In contrast to other studies, this research was conducted without using the weighting method; weighting was carried out by filling out the questionnaire by the Tosuka stakeholders. Then, the results of the survey were processed to be the priority weights of each level in the SCOR. So that we can know and conclude so far the supply chain management at Tosuka Coffee is at what level. If it is in a good category, this research can be a source of reference for MSME business players who are now developing rapidly in Indonesia. We hope this research can be useful for Tosuka and even other MSME businesses, especially related to knowledge about the benefits of supply chain management for their business processes.

\section{RESEARCH METHOD}

One method for estimating and assessing supply chains' performance is to use the SCOR (Supply Chain Operation Reference) model. The SCOR method is a model of managing processes in supply chain operations in the form of a description of business processes from the 
INTENSIF, Vol.4 No.2 August 2020

ISSN: 2580-409X (Print) / 2549-6824 (Online)

DOI: https://doi.org/10.29407/intensif.v4i2.13993

supplier to the customer by the objectives of the supply chain [13]. The SCOR method needs to consider change management and review issues related to the supply chain to produce a decision [14]. In the SCOR method, there are several processes in the supply chain, including, process plan, source process, make the process, delivery process, and return process [15]. The SCOR method consists of 3 levels of general to specific procedures that contain metrics that must be done in stages in determining the performance attributes. The advantages of the SCOR method are that it helps in understanding supply chains, facilitates supply analysis activities of chain performance, thus facilitating the connecting process between each event in the supply chain [16]. In SCOR, the indicators used are criteria to evaluate the performance of service products and procedures used to measure performance [17][18]. The application of the SCOR method can be applied to describe the supply chain performance indicators by detailing each existing process so that later it can be used as a reference in evaluating to improve performance [8].

The object of this research is Tosuka Coffee Patrajasa, which is located at Jl. Gatot Subroto, Kuningan, South Jakarta. The steps that have been taken are as follows.

1. Review the SCM system at UMuka Tosuka Coffee Patrajasa

Supply chain activities in Tosuka are carried out by several related parties. Researchers observed and collected data to find out the problems and supply chain systems in Tosuka Coffee. The mapping of the issues in Tosuka is in Chapter 1, while the Tosuka Coffee supply chain mapping can be seen in Figure 1 [19]. Tosuka Coffee supplies coffee beans, powder, palm sugar, cups for drinks, and coffee machines to different suppliers. The central branch of Tosuka Coffee checks the condition of the raw materials that have been supplied and ensures good quality. Then the employee records the raw material stock. Then the raw materials will be packaged and then sent to all branches of Tosuka Coffee. The return process can occur if the department returns in the form of goods or money. Then the Tosuka branch sells its products to consumers. Researchers conduct interviews with company owners relating to the supply chain system, along with management associated with providing goods and employees related to the production process.

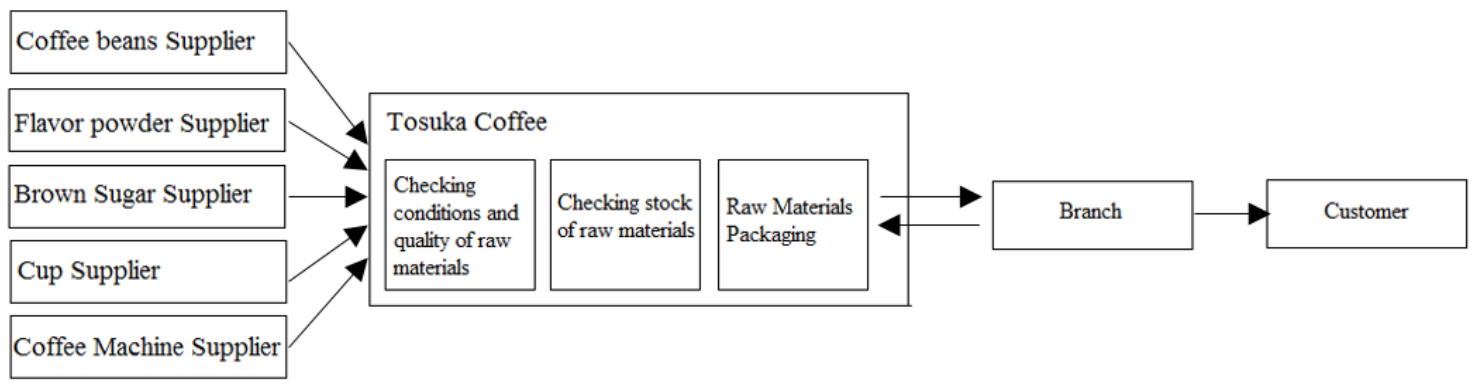

Figure 1. Business PROCESS AND SuPPly ChaIN TOSUKA COFFEE 
2. Determination of the Number of Respondents

The number of respondents in our study consisted of 8 people, including two as owners and investors, four management employees, and two baristas. We made these stakeholders the main respondents because they were considered to know the condition of the business processes of Tosuka regarding the supply chain system. We believe the number of respondents sufficient for stakeholders to understand the internal states of their business related to the supply chain system that has been implemented, so there is no need for respondents from the external environment (customers).

3. Calculation Analysis with the SCOR Approach

The steps that must be taken in measuring supply chain performance are as follows :

a. Determine Metrics at each Level

Identify a Level 1 metric containing the overall process size or general definition of the five core supply chain processes. These processes include Plan, Make, Source, Deliver, and Return. At Level 2, Metrics can be called a dimension that contains indicators consisting of attributes to measure SCM performance. These dimensions are Reliability, Responsiveness, Flexibility, Cost, and Asset. Reliability is the assessment of company performance in carrying out its tasks exactly as expected, responsiveness, which is the assessment of supply chain speed performance will reach the hands of customers, flexibility is the assessment of time in responding to market changes. Cost is the company's evaluation of the expenses in a supply chain, assets, namely, the assessment of the management of company property [20]. At level 3, examine and determine indicators that affect level 2 Metrics. These metrics can be called Key Performance Indicators (KPI) [15],[19].

Of the three levels that have been explained, the selection of performance indicators is following Tosuka's condition based on the results of an interview with Tosuka. Details of each level are in Table 1 [21],[22].

Table 1. IDENTIFYING THE INDICATORS EACH LEVEL

\begin{tabular}{cccc}
\hline \hline $\begin{array}{c}\text { Core Process } \\
\text { (Level 1) }\end{array}$ & $\begin{array}{c}\text { Dimension } \\
\text { (Level 2) }\end{array}$ & No. KPI & $\begin{array}{c}\text { Key Performance Indicator } \\
\text { (Level 3) }\end{array}$ \\
\hline \multirow{3}{*}{ Plan } & Reliability & PR-1 & Meeting with customers \\
\cline { 2 - 4 } & & PR-2 & Time approves employee performance. \\
\cline { 2 - 4 } & Responsiveness & PRe-1 & The period for the delivery of raw materials \\
\cline { 2 - 4 } & Asset & PRe-2 & The period for determining new product specifications \\
\cline { 2 - 4 } & PA & Cash to cash cycle time \\
\hline
\end{tabular}


INTENSIF, Vol.4 No.2 August 2020

ISSN: 2580-409X (Print) / 2549-6824 (Online)

DOI: https://doi.org/10.29407/intensif.v4i2.13993

Table 1. IDENTIFYING THE INDICATORS EACH LEVEL [CONTINUE]

\begin{tabular}{|c|c|c|c|}
\hline $\begin{array}{c}\text { Core Process } \\
\text { (Level 1) }\end{array}$ & $\begin{array}{c}\text { Dimension } \\
\text { (Level 2) }\end{array}$ & No. KPI & $\begin{array}{c}\text { Key Performance Indicator } \\
\text { (Level 3) }\end{array}$ \\
\hline \multirow{7}{*}{ Source } & \multirow{3}{*}{ Reliability } & SR-1 & Raw material defects \\
\hline & & SR-2 & Fulfillment of raw materials \\
\hline & & SR-3 & Reliability in shipping raw materials \\
\hline & Responsiveness & $\mathrm{SRe}$ & Lead time for raw material \\
\hline & Flexibility & SF & Supplier availability \\
\hline & Cost & $\mathrm{SC}$ & Order costs to suppliers \\
\hline & Asset & SA & Daily supplies \\
\hline \multirow{7}{*}{ Make } & \multirow{2}{*}{ Reliability } & MR-1 & Error in packing \\
\hline & & MR-2 & Number of defective products \\
\hline & \multirow[b]{2}{*}{ Responsiveness } & MRe-1 & Product manufacturing time \\
\hline & & MRe-2 & Responsiveness in serving customer orders \\
\hline & Flexibility & MF & Flexibility in product delivery \\
\hline & Cost & $\mathrm{MC}$ & Shipping costs \\
\hline & Asset & MA & The average length of life of a coffee machine \\
\hline \multirow{3}{*}{ Deliver } & \multirow{2}{*}{ Reliability } & DR-1 & Fulfillment of raw materials \\
\hline & & DR-2 & Raw material stock levels \\
\hline & Responsiveness & $\mathrm{DRe}$ & Lead time for raw material \\
\hline \multirow{2}{*}{ Return } & Reliability & RR & The level of complaints from customers \\
\hline & Responsiveness & $\mathrm{RRe}$ & Time to replace damaged products \\
\hline
\end{tabular}

b. The data processing stage is calculating the value of each KPI metric along with the normalization (score) of each parameter calculated by the Snorm De Boer normalization calculation, which can be seen in equation (1), as well as with other alternatives namely comparison (2). Snorm De Boer normalization aims to adjust the metric value to be used as an indicator in measuring KPI metrics [8]. Changing the normalized value scale of the sign is then converted into a range of 0 to 100 .

$$
\begin{aligned}
& \text { Snorm atau Skor }=\frac{(S i-S \min )}{(S \max -S \min )} \times 100 \\
& \text { atau } \frac{(\text { Si-Smin })}{(S \max -S \min )}=\frac{\text { skor }-0}{100-0}
\end{aligned}
$$

with $S_{i}$ is the indicator value achieved; $S_{\min }$ is the achievement value of the worst performance on performance indicators; $S_{\max }=$ the best performance value of a performance indicator. In this calculation, each weight of the indicator is converted into a

164 INTENSIF: Jurnal Ilmiah Penelitian dan Penerapan Teknologi Sistem Informasi 
INTENSIF, Vol.4 No.2 August 2020

ISSN: 2580-409X (Print) / 2549-6824 (Online)

DOI: https://doi.org/10.29407/intensif.v4i2.13993

range of values ranging from 0 to 100 . A zero (0) value is interpreted as the worst, and a hundred (100) cost is understood as the best. From the results of the parameter values for each indicator, analysis and conclusions can be made later. Table 2 is the reference standard in the monitoring level reference standard on performance indicators [10].

Table 2. LEVEL MONITORING PERFORMANCE INDICATORS

\begin{tabular}{cc}
\hline \hline Monitoring Level & Performance Indicator \\
\hline$<40$ & Poor \\
\hline $40-50$ & Marginal \\
\hline $50-70$ & Average \\
\hline $70-90$ & Good \\
\hline$>90$ & Excellent \\
\hline
\end{tabular}

c. Determine the weights for each process, dimensions, and KPI indicators. Determination of the weight is done by distributing questionnaires to the respondents listed in step $b$. Each process, size, and the index has different influences. The results of the survey are then normalized into a weighting equation:

$$
\frac{W j}{\sum W j}
$$

With $W j$ is the value after conversion, $\sum$ is the total number.

d. Calculating the Final Value Performance can be obtained by multiplying each normalized value by the weight value of each metric. Calculating the final cost of performance consists of 3 stages. The first step is estimating the value of the KPI indicator, calculating the value of each dimension, and calculating each process's value.

e. Analysis and Conclusions contain a detailed description of the results of supply chain performance research. From the study, it can be seen which metrics have low value and need to be improved.

\section{RESULT AND DISCUSSION}

\section{Calculation of normalized matrix values}

Based on the KPI indicators that have been mapped in table 1, each KPI indicator is given a different score among other symbols; the aim is to determine which process needs to be evaluated based on the rating [23]. This score is obtained from the results of filling out the questionnaire by respondents. Then the score is normalized by the Snorm De Boer equation. The normalization process is applied to all Key Performance Indicators (KPI). 
INTENSIF, Vol.4 No.2 August 2020

ISSN: 2580-409X (Print) / 2549-6824 (Online)

DOI: https://doi.org/10.29407/intensif.v4i2.13993

For example, on KPI PR-1 (meeting with customers) with the value that has been achieved $(\mathrm{Si})=3$, the maximum value $(\mathrm{Smax})=5$, the minimum amount $(\mathrm{Smin})=0$. Calculation with equation (1) :

$$
P R-1=\frac{(3-0)}{(5-0)} \times 100=60
$$

Furthermore, all KPI values can be calculated in the same way. Table 3 presents a recapitulation of KPI normalization results.

Table 3. RECAPITULATION OF KPI NORMALIZATION RESUlTS

\begin{tabular}{|c|c|c|c|}
\hline $\begin{array}{c}\text { Dimension } \\
\text { (Level 2) }\end{array}$ & No. KPI & Indicator & Score \\
\hline \multirow{2}{*}{ Reliability } & PR-1 & Meeting with customers & 60 \\
\hline & PR-2 & Time approves employee performance & 80 \\
\hline \multirow{2}{*}{ Responsiveness } & PRe-1 & The period for the delivery of raw materials & 80 \\
\hline & PRe-2 & The period for determining new product specifications & 60 \\
\hline Asset & $\mathrm{PA}$ & Cash to cash cycle time & 100 \\
\hline \multirow{3}{*}{ Reliability } & SR-1 & Raw material defects & 80 \\
\hline & SR-2 & Fulfillment of raw materials & 100 \\
\hline & SR-3 & Reliability in shipping raw materials & 80 \\
\hline Responsiveness & $\mathrm{SRe}$ & Lead time for raw material & 100 \\
\hline Flexibility & SF & Supplier availability & 100 \\
\hline Cost & $\mathrm{SC}$ & Order costs to suppliers & 80 \\
\hline Asset & SA & Daily supplies & 100 \\
\hline \multirow{2}{*}{ Reliability } & MR-1 & Error in packing & 80 \\
\hline & MR-2 & Number of defective products & 80 \\
\hline \multirow{2}{*}{ Responsiveness } & MRe-1 & Product manufacturing time & 100 \\
\hline & MRe-2 & Responsiveness in serving customer orders & 100 \\
\hline Flexibility & MF & Flexibility in product delivery & 100 \\
\hline Cost & $\mathrm{MC}$ & Shipping costs & 100 \\
\hline Asset & MA & The average length of life of a coffee machine & 60 \\
\hline \multirow{2}{*}{ Reliability } & DR-1 & Fulfillment of raw materials & 100 \\
\hline & DR-2 & Raw material stock levels & 80 \\
\hline Responsiveness & $\mathrm{DRe}$ & Lead time for raw material & 60 \\
\hline Reliability & RR & The level of complaints from customers & 100 \\
\hline Responsiveness & $\mathrm{RRe}$ & Time to replace damaged products & 100 \\
\hline
\end{tabular}


INTENSIF, Vol.4 No.2 August 2020

ISSN: 2580-409X (Print) / 2549-6824 (Online)

DOI: https://doi.org/10.29407/intensif.v4i2.13993

\section{Determining Weight Weights}

The next stage is determining the weight of each process, dimensions, and KPI indicators. In this study, the weighting is done by conducting interviews and filling in the questionnaire with UMKM Tosuka Coffee stakeholders by choosing a scale of 1-5 where one means priority and 5 means 5 th priority. The results of the survey are converted upside down, aiming that the priority has the greatest weight. Convert scale 1 to 5,2 to 4 , and range 3 with the same position. Next, calculate the field that has been converted using equation (3).

For example, the Plan process gets priority scale 1, which is then converted to 5. Next divided by the total scale $(5+4+3+2+1)$

$$
\text { Plan }=\frac{5}{15}=0,333
$$

So the weight in the Plan process is 0.33 . Then every process, dimension, and KPI are calculated in the same way. Table 4 shows the recapitulation of the weight values at each level.

Table 4. WEIGHT EVERY LEVEL

\begin{tabular}{|c|c|c|c|c|c|}
\hline $\begin{array}{c}\text { Core Process } \\
\text { (Level 1) }\end{array}$ & Weight & $\begin{array}{c}\text { Dimension } \\
\text { (Level 2) }\end{array}$ & Weight & KPI (Level 3) & Weight \\
\hline \multirow{5}{*}{ Plan } & \multirow{5}{*}{0.33} & \multirow[b]{2}{*}{ Reliability } & \multirow[b]{2}{*}{0.17} & Meeting with customers & 0.67 \\
\hline & & & & Time approves employee performance & 0.33 \\
\hline & & \multirow[b]{2}{*}{ Responsiveness } & \multirow[b]{2}{*}{0.50} & Time approves employee performance & 0.67 \\
\hline & & & & The period for the delivery of raw materials & 0.33 \\
\hline & & Asset & 0.33 & $\begin{array}{c}\text { The period for determining new product } \\
\text { specifications }\end{array}$ & 1.00 \\
\hline \multirow{7}{*}{ Source } & \multirow{7}{*}{0.13} & \multirow{3}{*}{ Reliability } & \multirow{3}{*}{0.13} & Cash to cash cycle time & 0.33 \\
\hline & & & & Raw material defects & 0.50 \\
\hline & & & & Fulfillment of raw materials & 0.17 \\
\hline & & Responsiveness & 0.27 & Reliability in shipping raw materials & 1.00 \\
\hline & & Flexibility & 0.20 & Lead time for raw material & 1.00 \\
\hline & & Cost & 0.33 & Supplier availability & 1.00 \\
\hline & & Asset & 0.07 & Order costs to suppliers & 1.00 \\
\hline \multirow{7}{*}{ Make } & \multirow{7}{*}{0.07} & \multirow{2}{*}{ Reliability } & \multirow{2}{*}{0.13} & Daily supplies & 0.33 \\
\hline & & & & Error in packing & 0.67 \\
\hline & & \multirow[b]{2}{*}{ Responsiveness } & \multirow[b]{2}{*}{0.20} & Number of defective products & 0.33 \\
\hline & & & & Product manufacturing time & 0.67 \\
\hline & & Flexibility & 0.33 & Responsiveness in serving customer orders & 1.00 \\
\hline & & Cost & 0.27 & Flexibility in product delivery & 1.00 \\
\hline & & Asset & 0.07 & Shipping costs & 1.00 \\
\hline
\end{tabular}


INTENSIF, Vol.4 No.2 August 2020

ISSN: 2580-409X (Print) / 2549-6824 (Online)

DOI: https://doi.org/10.29407/intensif.v4i2.13993

Table 4. WEIGHT EVERY LEVEL [CONTINUE]

\begin{tabular}{cccccc}
\hline \hline $\begin{array}{c}\text { Core Process } \\
\text { (Level 1) }\end{array}$ & Weight & $\begin{array}{c}\text { Dimension } \\
\text { (Level 2) }\end{array}$ & Weight & KPI (Level 3) & Weight \\
\hline \multirow{2}{*}{ Deliver } & \multirow{2}{*}{0.20} & Reliability & 0.33 & The average length of life of a coffee machine & 0.67 \\
\cline { 3 - 6 } & & Responsiveness & 0.67 & Fulfillment of raw materials & 0.33 \\
\hline \multirow{2}{*}{ Return } & \multirow{2}{*}{0.27} & Reliability & 0.67 & Raw material stock levels & 1.00 \\
\cline { 3 - 6 } & & Responsiveness & 0.33 & The level of complaints from customers & 1.00 \\
\hline
\end{tabular}

3. Calculate the final value of performance, consisting of three stages. The first stage calculates the final KPI value by multiplying the KPI score by the weight of the KPI indicator.

Table 5. Calculation OF KPI END VAlues

\begin{tabular}{|c|c|c|c|c|c|}
\hline $\begin{array}{l}\text { No } \\
\text { KPI }\end{array}$ & KPI & Score & Weight & KPI value & $\begin{array}{c}\text { Total } \\
\text { Dimensions }\end{array}$ \\
\hline PR-1 & Meeting with customers & 60 & 0.67 & 40 & \multirow{2}{*}{66.66666667} \\
\hline PR-2 & Time approves employee performance & 80 & 0.33 & 26.66666667 & \\
\hline PRe-1 & The period for the delivery of raw materials & 80 & 0.67 & 53.33333333 & \multirow{2}{*}{73.33333333} \\
\hline PRe-2 & The period for determining new product specifications & 60 & 0.33 & 20 & \\
\hline PA & Cash to cash cycle time & 100 & 1.00 & 100 & 100 \\
\hline SR-1 & Raw material defects & 80 & 0.33 & 26.66666667 & \multirow{3}{*}{90} \\
\hline SR-2 & Fulfillment of raw materials & 100 & 0.50 & 50 & \\
\hline SR-3 & Reliability in shipping raw materials & 80 & 0.17 & 13.33333333 & \\
\hline $\mathrm{SRe}$ & Lead time for raw material & 100 & 1.00 & 100 & 100 \\
\hline SF & Supplier availability & 100 & 1.00 & 100 & 100 \\
\hline $\mathrm{SC}$ & Order costs to suppliers & 80 & 1.00 & 80 & 80 \\
\hline SA & Daily supplies & 100 & 1.00 & 100 & 100 \\
\hline MR-1 & Error in packing & 80 & 0.33 & 26.66666667 & \multirow{2}{*}{80} \\
\hline MR-2 & Number of defective products & 80 & 0.67 & 53.33333333 & \\
\hline MRe-1 & Product manufacturing time & 100 & 0.33 & 33.33333333 & \multirow{2}{*}{100} \\
\hline MRe-2 & Responsiveness in serving customer orders & 100 & 0.67 & 66.66666667 & \\
\hline $\mathrm{MF}$ & Flexibility in product delivery & 100 & 1.00 & 100 & 100 \\
\hline $\mathrm{MC}$ & Shipping costs & 100 & 1.00 & 100 & 100 \\
\hline MA & The average length of life of a coffee machine & 60 & 1.00 & 60 & 60 \\
\hline DR-1 & Fulfillment of raw materials & 100 & 0.67 & 66.66666667 & \multirow{2}{*}{93.33333333} \\
\hline DR-2 & Raw material stock levels & 80 & 0.33 & 26.66666667 & \\
\hline Dre & Lead time for raw material & 60 & 1.00 & 60 & 60 \\
\hline RR & The level of complaints from customers & 100 & 1.00 & 100 & 100 \\
\hline $\mathrm{RRe}$ & Time to replace damaged products & 100 & 1.00 & 100 & 100 \\
\hline
\end{tabular}


INTENSIF, Vol.4 No.2 August 2020

ISSN: 2580-409X (Print) / 2549-6824 (Online)

DOI: https://doi.org/10.29407/intensif.v4i2.13993

The second step calculates the final value of each dimension. After calculating the final KPI value, the total amount of each aspect is obtained from the sum of the indicators on one size. The results of the overall calculation of each dimension on the KPI are used for further calculations to get the total value of each process.

Table 6. Calculation Of End Dimensional Value

\begin{tabular}{|c|c|c|c|c|c|}
\hline $\begin{array}{l}\text { Process } \\
\text { (Level 1) }\end{array}$ & $\begin{array}{c}\text { Dimension } \\
\text { (Level 2) }\end{array}$ & Score & Weight & $\begin{array}{c}\text { Performance Value } \\
\text { (Score x Weight) }\end{array}$ & Total Process \\
\hline \multirow{3}{*}{ Plan } & Reliability & 66.67 & 0.17 & 11.11166667 & \multirow{3}{*}{81.11} \\
\hline & Responsiveness & 73.33 & 0.50 & 36.665 & \\
\hline & Asset & 100 & 0.33 & 33.33333333 & \\
\hline \multirow{5}{*}{ Source } & Reliability & 90 & 0.13 & 12 & \multirow{5}{*}{92} \\
\hline & Responsiveness & 100 & 0.27 & 26.666666667 & \\
\hline & Flexibility & 100 & 0.20 & 20 & \\
\hline & Cost & 80 & 0.33 & 26.666666667 & \\
\hline & Asset & 100 & 0.07 & 6.6666666667 & \\
\hline \multirow{5}{*}{ Make } & Reliability & 80 & 0.13 & 10.666666667 & \multirow{5}{*}{90.66666667} \\
\hline & Responsiveness & 80 & 0.20 & 16 & \\
\hline & Flexibility & 100 & 0.33 & 33.33333333 & \\
\hline & Cost & 100 & 0.27 & 26.666666667 & \\
\hline & Asset & 60 & 0.07 & 4 & \\
\hline \multirow[t]{2}{*}{ Deliver } & Reliability & 93.33 & 0.33 & 31.11 & \multirow[t]{2}{*}{71.11} \\
\hline & Responsiveness & 60 & 0.67 & 40 & \\
\hline \multirow{2}{*}{ Return } & Reliability & 100 & 0.67 & 66.666666667 & \multirow[b]{2}{*}{100} \\
\hline & Responsiveness & 100 & 0.33 & 33.33333333 & \\
\hline
\end{tabular}

The third step is to calculate the final value of each process. The calculation of the final cost of the dimension will produce a total amount of each method. The value is obtained from the score of each size multiplied by the weight of each aspect. 
INTENSIF, Vol.4 No.2 August 2020

ISSN: 2580-409X (Print) / 2549-6824 (Online)

DOI: https://doi.org/10.29407/intensif.v4i2.13993

Table 7. Calculation Of Final Value Process (Performance Value)

\begin{tabular}{cccc}
\hline \hline Process & Score & Weight & Final Score (Score * Weight) \\
\hline Plan & 81.11 & 0.33 & 27.036 \\
\hline Source & 92 & 0.13 & 12.26 \\
\hline Make & 90.67 & 0.07 & 6.04 \\
\hline Deliver & 71.11 & 0.20 & 14.22 \\
\hline Return & 100 & 0.27 & 26.66 \\
\hline & Total & & 86.23
\end{tabular}

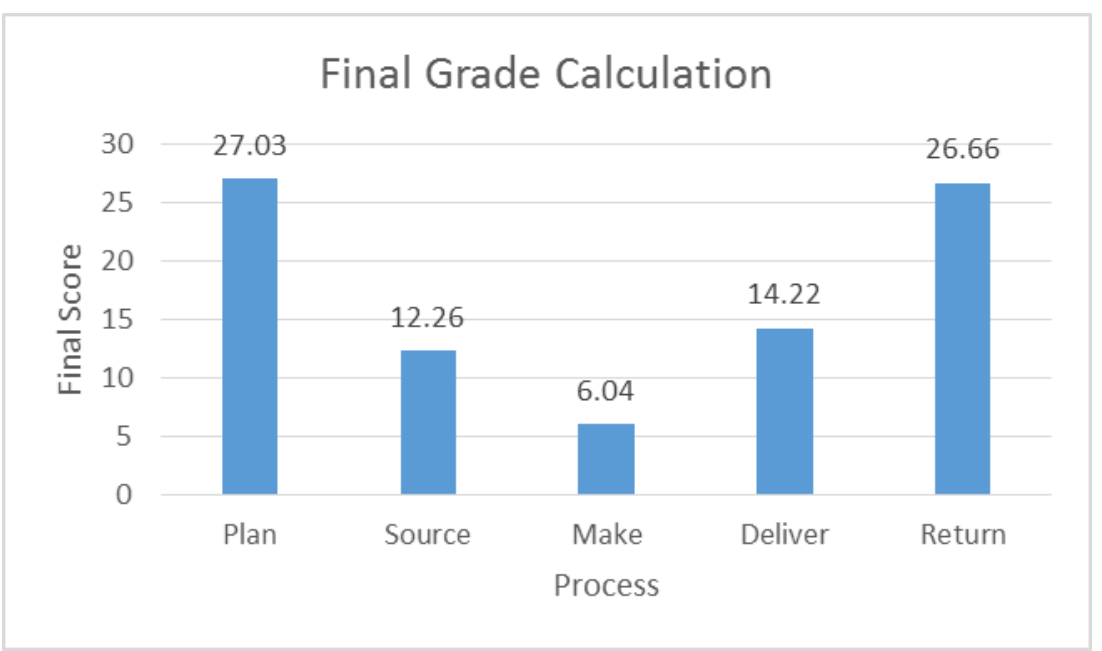

Figure 2. Calculation Of Final Value Process (Performance Value)

4. Analysis Result

Table 7 and graph one have been made; the final value of supply chain performance in Tosuka Coffee is obtained at 86.24. The highest value is purchased in the Plan process with a cost of 27.03 ; then, in the second position, the Return process is achieved with a value of 26.67 , then the method of delivery, source, and make with each value. The example in the Make process of the MR-1 indicator has a low cost, namely an error in the delivery. It is because often, the order of raw material sources obtained does not match the desired order. Another example in the DR-2 delivery indicator process section is the level of raw material stock. It is due to the lack of accuracy of employees who do not do regular stocktaking. It is recommended that employees and managers always ensure consistent stock availability, starting with a proper and detailed inventory of raw materials and direct operational monitoring. However, when referring to table 2 , the overall final value of supply chain performance in Tosuka is classified as a good level. 


\section{CONCLUSION}

Based on the analysis in the previous chapter, it is known that the highest final value of supply chain performance is in the process plant with a cost of 27.03 and a return with a value of 26.67. The total amount of overall supply chain performance is 86.24 , which is classified as a good level. So the evaluation that has been carried out concluded that the current tosuka performance is at a fairly good level. However, there are still shortcomings, especially in the make, source, and delivery processes. What will need to be improved and improved from the supply chain performance? The need to increase supply chain performance in Tosuka Coffee can be done in stages in the Make, Source, and Deliver processes. It is best to carry out a routine and comprehensive monitoring and controlling process, starting from the lowest to the highest level of workers. For further research, we suggest using methods intended for performance-based calculations, including Balanced Scorecard, Activity Based Costing (ABC), Economic Value Analysis (EVA) [17], and many more. And researchers can then expand the scope of SMEs to be studied.

\section{REFERENCES}

[1] S. Azmiyati and S. Hidayat, "Pengukuran Kinerja Rantai Pasok pada PT. Louserindo Megah Permai Menggunakan Model SCOR dan FAHP," Tek. Ind. Univ. Al Azhar Indones., vol. 3, no. 4, pp. 163-170, 2016.

[2] N. S. Maulidiya, N. W. Setyanto, and R. Yuniarti, "Pengukuran Kinerja Supply Chain berdasarkan Proses Inti PADA Supply Chain Operation Reference ( SCOR )," Tek. Ind. Univ. Brawijaya, no. 2006, pp. 696-705, 2015.

[3] F. Diah, R. Syarief, and Marimin, "Pengukuran dan Perbaikan Kinerja Rantai Pasok UKM Lapis Bogor Sangkuriang Untuk Meningkatkan Daya Saing UKM," J. Teknol., vol. 26, no. 2, pp. 199-206, 2016.

[4] Heriyanto, "Aplikasi Rantai Pasok Pada Usaha Kecil Menengah Di Kota Palembang," Proc. Semin. Nas. Call Pap., pp. 1-10, 2019.

[5] A. Nugroho and A. Rofiq, "UKM Kripik Tempe Menggunakan Metode SEM Supply Chain Management Analysis using SEM Method in Keripik tempe Industry," Teknol. Pertan., vol. 18, no. 3, pp. 153-162, 2017.

[6] I. D. Made and A. Baskara, "Analisa Implementasi E-SCM Pada Model Bisnis Distribution Outlet (DISTRO)," J. Pendidik. Teknol. dan Kejuru., vol. 15, no. January, p. 146, 2018.

[7] D. Apriyani and R. Nurmalina, "Evaluasi Kinerja Rantai Pasok Sayuran Organik Dengan Pendekatan Supply Chain Operation Reference (SCOR)," Fak. Ekon. Inst. Pertan. Bogor, vol. 8, no. 2, pp. 312-335, 2018.

[8] R. Wahyuniardi and M. Syarwani, "Pengukuran Kinerja Supply Chain Dengan Pendekatan Supply Chain Operation References ( SCOR )," J. Ilm. Tek. Ind., no. 14126869, 2017.

[9] Q. Aini, A. M. Pratama, and F. D. Yasmin, "Analisis Kinerja Rantai Pasok dengan Supply Chain Operation Research (SCOR) dan AHP," Sebatik, UIN Syarif Hidayatullah, pp. 20-27, 2018.

[10] D. T. Liputra and N. A. Susanto, "Pengukuran Kinerja Rantai Pasok Dengan Model 
INTENSIF, Vol.4 No.2 August 2020

ISSN: 2580-409X (Print) / 2549-6824 (Online)

DOI: https://doi.org/10.29407/intensif.v4i2.13993

Supply Chain Operations Reference (SCOR) dan Metode Perbandingan Berpasangan," $J$. Rekayasa Sist. Ind., vol. 7, no. 2, pp. 1-8, 2018.

[11] F. N. Firdaus, Yuniristanto, and R. Zakaria, "Evaluasi Kinerja Sistem Rantai Pasok Meja Tenis Meja Menggunakan Metode SCOR," J. Ilmu Manaj., vol. 8, no. 3, pp. 657-677, 2018.

[12] D. Amalia, "Analisis Pengaruh Praktek Supply Chain Management, Integrasi Supply Chain, dan Kapabilitas Bersaing Terhadap Kinerja (UKM Eksportir di Kodya Yogyakarta)," 2013.

[13] C. Natalia and R. Astuario, "Penerapan Model Green SCOR untuk Pengukuran Kinerja Green Supply Chain," J. Metris, vol. 16, pp. 97-106, 2015.

[14] S. H. Huan, S. K. Sheoran, and G. Wang, "Supply Chain Management: A review and analysis of supply chain operations reference (SCOR) model," Int. J. Emerald Artic., vol. 9, no. 1, pp. 23-29, 2004.

[15] A. Mutakin and M. Hubeis, "Pengukuran Kinerja Manajemen Rantai Pasokan dengan SCOR (Studi Kasus di PT Indocement Tunggal Prakarsa Tbk)," J. Manajemen, Fak. Ekon. Inst. Pertan. Bogor, vol. II, no. 3, pp. 89-103, 2011.

[16] A. H. Sutawijaya and E. Marlapa, "Supply Chain Management : Analisis dan Penerapan Menggunakan SCOR di PT. Indoturbine," Univ. Mercubuana, J. Ilm. Manaj., vol. VI, no. 1, pp. 121-138, 2016.

[17] I. M. Ambe, "Key Indicators For Optimising Supply Chain Performance," J. Appl. Bus. Res., vol. 30, no. 1, pp. 277-290, 2014.

[18] D. Irfan, X. Xiaofei, and D. S. Chun, "A SCOR Reference Model of the Supply Chain Management System in an Enterprise," Int. Arab J. Inf. Technol., vol. 5, no. 3, pp. 288295, 2008.

[19] M. Hartati and D. Efendi, "Analisis Pengukuran Kinerja Aliran Supply Chain di PT . Asia Forestama Raya dengan Metode Supply Chain Operation Reference ( SCOR )," Proc. Semin. Nas. Rekayasa Teknol. Ind. dan Inf., 2016.

[20] A. S. Slamet, Y. Arkeman, F. Udin, and Marimin, "Integrasi Model SCOR dan Fuzzy AHP untuk Perancangan Metrik Pengukuran Integrasi Model SCOR dan Fuzzy AHP untuk Perancangan Metrik Pengukuran Kinerja Rantai Pasok Sayuran,” Insitut Pertan. Bogor, no. January, 2014.

[21] S. Duwimustaroh, R. Astuti, and E. R. Lestari, "Analisis Kinerja Rantai Pasok Kacang Mete dengan Metode Data Envelopment Analysis (DEA) di PT Supa Surya Niaga, Sidoarjo," J. Teknol. dan Manaj. Argoindustri, vol. 5 (3), pp. 169-180, 2016.

[22] A. Purnomo, "Analisis Kinerja Rantai Pasok Menggunakan Metode Supply Chain Operation Reference (SCOR) di Sektor Industri Produk Tekstil," J. Univ. Pas., no. 2012, pp. 739-746, 2014.

[23] A. N. Waaly, A. Y. Ridwan, and M. D. Akbar, "Supply Chain Operation Reference (SCOR) Model dan Analitycal Hierarchy Process (AHP)," J. Ind. Serv., vol. 4, no. 1, pp. $1-6,2018$. 